\title{
CHAPTER 10 \\ Vulnerable Populations and Regions: \\ Middle East as a Case Study
}

\author{
Wael K. Al-Delaimy
}

\begin{abstract}
Summary There are published analyses predicting that the Middle East and North Africa (MENA) region will be the most affected by climate change and global warming. This region has a multitude of factors that makes it more vulnerable to climate change. It is the first region in the world expected to run out of fresh water. It has diversity in income levels between one country and another, but most lowincome countries rely on farming and agriculture that is rain-dependent, and there is poor governance and lack of resources to address the impact of climate change through adaptation. There is genuine interest by the MENA countries to address climate change through submission of Intended Nationally Determined Contributions by many countries in the region, but there is a lack of implementation with regard to climate change action plans and no public awareness within countries in the region. The heat waves, sand storms, declines in agriculture and food security, declines in water access, and associated health outcomes in this region are going to drive more migration within and outside the specific countries. The health impact from these climate change scenarios will be overwhelming in many regions in MENA, even if the target $2{ }^{\circ} \mathrm{C}$ global minimum temperature increase is achieved. There is a dearth of data from the MENA region regarding climate change and its impact on health.
\end{abstract}

\section{Historical and Religious Relevance}

The MENA region is identified differently by different entities, but for the purpose of this chapter it is represented by the predominately Arab countries (Morocco, Algeria, Tunisia, Libya, Egypt and Sudan in North Africa, and Syria, Lebanon, Palestine, Jordan, Iraq, Saudi Arabia, Yemen, Oman, Kuwait, Qatar, United Arab Emirates-

W. K. Al-Delaimy $(\bowtie)$

University of California San Diego, La Jolla, CA, USA

e-mail: waldelaimy@ucsd.edu 
UAE, and Bahrain in the Middle East) as well as Iran, based on the World Bank criteria. This area is inhabited by predominantly Arab ethnic groups, of whom the majority (91.2\%) are Muslims (Pew Research Center, 2011). The origin of the Arabs in the region goes back to nomadic tribes roaming the region in search of pasture and water for their livestock through regular seasonal migration in search of these resources. The Arabs have been in the desert in the Arabian Peninsula or in farming rural communities in Iraq, Syria, Palestine, Egypt, and coastal Mediterranean countries. With increasing affluence in the past century, most of the migration has been internal from rural areas to cities, which offer more secure and higher paying jobs. This trend has changed recently with increasing migration out of the region because of conflicts and political instability, and is likely exacerbated by global warming impacts.

The Quran, Islam's Holy Scripture, documents a clearly identifiable historical severe drought in great detail, which is corroborated by other Biblical and Judaic Scripture. Prophet Joseph, son of Prophet Jacob who is revered by Muslims, Christians, and Jews, lived around 600 B.C. and relayed his experiences of a 7-year drought that affected all of today's Egypt, Palestine, Israel, Lebanon, Syria, and Jordan in the MENA region. Many lessons are provided by the story of Joseph and the drought that apply to the region today, which includes good governance, adaptation, and conservation. This concept is typically overlooked by the public, who read the verses of the Quran about the story of Joseph but do not relate it to today's climate change, drought, and needed adaptation measures. Other teachings of Islam through the Holy text in the Quran that clearly point to the role of mankind in destroying the planet include Chapter 30 verse 41: Corruption has appeared in the land and the sea on account of what the hands of men have wrought, that He may make them taste a part of that which they have done, so that they may return. The teaching of Prophet Mohamed has many examples relevant to protecting the planet as a duty (He said, Don't waste water even if you are on the bank of a flowing river; He also said, if the end of the world happened while you are planting a tree, continue planting it - to overemphasize the importance of planting trees). This teaching in Islam is supportive of an anthropogenic origin of climate change, as well as the means to mitigate it and to protect the resources of the planet.

\section{Extreme Heat Wave Events}

The occurrence of frequent heat waves is a direct manifestation of climate change and has impacted many countries in recent years. Extreme heat waves are events with record temperatures beyond the usual average heat wave event. Extreme heat waves are expected to cause several countries in the Arabian/Persian Gulf area to exceed the capacity of humans to be outdoors during summer periods (Lelieveld, et al., 2016; Pal \& Eltahir, 2016; World Bank, 2014a). The Warm Spell Duration Index (WSDI) is defined as the annual or seasonal count of days with at least 6 consecutive days of a warm spell. During this warm spell, the maximum tempera- 
ture each day is above the 90th percentile of past daily temperatures that occurred at the same time of the year during 1979-2009. In a $4{ }^{\circ} \mathrm{C}$ scenario, $80 \%$ of summer months are projected to be hotter than 5-standard deviations above the average (unprecedented heat extremes) by 2100 , and about $65 \%$ are projected to be hotter than 5-standard deviations above the average during the 2071-2099 period (see Fig. 10.1). In a $2{ }^{\circ} \mathrm{C}$ scenario, the annual number of hot days with exceptionally high temperatures and high thermal discomfort is expected to increase in several capital cities, from 4 to 62 days in Amman (Jordan), from 8 to 90 days in Baghdad (Iraq), and from 1 to 71 days in Damascus (Syria). The greatest increase is expected in Riyadh (Saudi Arabia), where the number of these extremely hot days is pro-
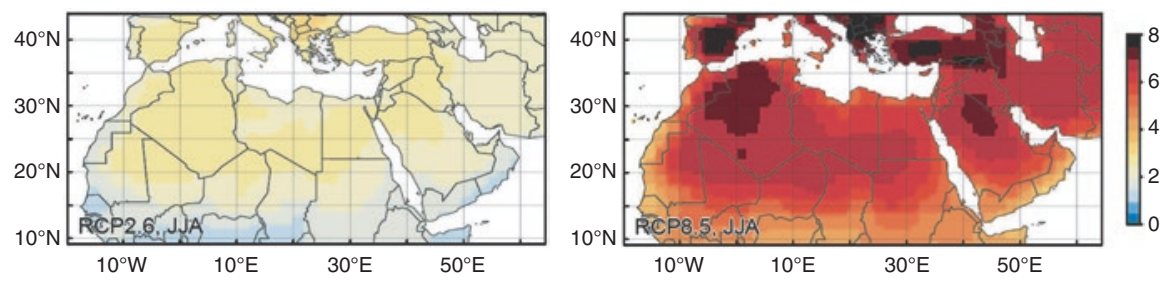

Fig. 10.1 Multi-model mean temperature anomaly for RCP2.6 $\left(2{ }^{\circ} \mathrm{C}\right.$ world, left $)$ and RCP8.5 ( $4{ }^{\circ} \mathrm{C}$ world, right) for the months of June-July-August for the Middle East and North African region (temperature anomalies in degrees Celsius are averaged over the time period 2071-2099 relative to 1951-1980) (From World Bank, 2014a)

Table 10.1 Mean WSDI (Warm Spell Duration Index) for capital cities in the MENA region for different levels of global warming based on regional climate model projections (World Bank, 2014a)

\begin{tabular}{l|l|c|l|l|l|l}
\hline & Period of observation & Observed & 1.5 & 2.0 & 3.0 & 4.0 \\
\hline Abadan & $1951-2000$ & 6 & 43 & 82 & 99 & 134 \\
\hline Amman & $1959-2004$ & 4 & 31 & 62 & 84 & 115 \\
\hline Ankara & $1926-2003$ & 7 & 44 & 67 & 111 & 128 \\
\hline Athens & $1951-2001$ & 1 & 40 & 61 & 121 & 166 \\
\hline Baghdad & $1950-2000$ & 8 & 47 & 90 & 113 & 162 \\
\hline Beirut & - & - & 47 & 93 & 126 & 187 \\
\hline Belgrade & $1951-2010$ & 9 & 39 & 39 & 76 & 113 \\
\hline Cairo & - & - & 32 & 53 & 80 & 94 \\
\hline Damascus & $1965-1993$ & 1 & 36 & 71 & 98 & 129 \\
\hline Istanbul & $1960-2010$ & 0 & 26 & 41 & 78 & 113 \\
\hline Jerusalem & $1964-2004$ & 7 & 26 & 46 & 73 & 102 \\
\hline Kuwait & - & - & 45 & 87 & 123 & 167 \\
\hline Nicosia & $1975-2001$ & 6 & 25 & 58 & 81 & 162 \\
\hline Riyadh & $1970-2004$ & 3 & 81 & 132 & 157 & 202 \\
\hline Sofia & $1960-2010$ & 1 & 40 & 49 & 88 & 136 \\
\hline Tehran & $1956-1999$ & 5 & 48 & 92 & 122 & 159 \\
\hline Tirana & $1951-2000$ & 6 & 49 & 71 & 125 & 168 \\
\hline Tripoli & $1956-1999$ & 3 & 13 & 22 & 33 & 59 \\
\hline
\end{tabular}





$20 \begin{array}{lllllllllllllll}21 & 22 & 23 & 24 & 25 & 26 & 27 & 28 & 29 & 30 & 31 & 32 & 33 & 34 & 35\end{array}$

${ }^{\circ} \mathrm{C}$

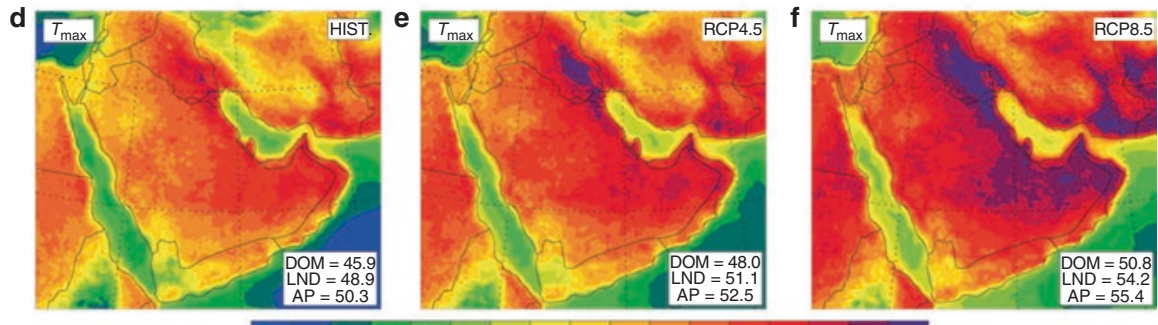

$\begin{array}{llllllllllllllll}30 & 32 & 34 & 36 & 38 & 40 & 42 & 44 & 46 & 48 & 50 & 52 & 54 & 56 & 58 & 60\end{array}$

Fig. 10.2 Spatial distributions of extreme wet bulb temperature and extreme temperature. (a-f) Ensemble average of the 30-year maximum TWmax (a-c) and Tmax (d-f) temperatures for each GHG scenario: historical (a, d), RCP4.5 (b, e) and RCP8.5 (c, f). Averages for the domain excluding the buffer zone (DOM), land excluding the buffer zone (LND) and the Arabian Peninsula (AP) are indicated in each plot. $\mathrm{TW}_{\max }$ and $\mathrm{T}_{\max }$ are the maximum daily values averaged over a 6-h window (From Pal \& Eltahir, 2016 reprinted with permission)

jected to rise from 3 to 132 days per year. In a $4{ }^{\circ} \mathrm{C}$ world, the average number of such days is projected to exceed 115 days per year in all of these cities (see Table 10.1 and Fig. 10.2) (Pal \& Eltahir, 2016).

Heat waves have been shown to be related to increased mortality across many countries (Guo, et al., 2017) and with some recent heat waves receiving wide media attention coverage for their high death tolls, such as the 2003 European heat wave that caused an estimated 70,000 deaths (Robine, Cheung, Le Roy et al., 2008) and the 2010 Russian heat wave that caused an estimated 11,000 deaths (Shaposhnikov et al., 2014). Heat stroke, exhaustion, and hyperthermia are the most common causes of mortality, but other causes of mortality from respiratory, cardiovascular and diabetic complications have also been demonstrated (Ye et al., 2012). However, there is limited data describing the impact of heat waves on health in the MENA region. Given the extreme temperatures expected from the business-as-usual scenario leading to a $4{ }^{\circ} \mathrm{C}$ increase in temperature, the resulting mortality from high temperatures in the MENA is going to be the highest in history because $80 \%$ of summer is going to have temperatures that are 5-standard deviations above the average temperature. The fact that temperatures have never reached $60{ }^{\circ} \mathrm{C}$, but are expected to reach such levels by the end of this century in the Gulf Region, means the health impact will be devastating. While the European heat wave claimed so many lives when reaching $37-41{ }^{\circ} \mathrm{C}$ 
for 9 consecutive days, the number of deaths will be much higher if reaching $60{ }^{\circ} \mathrm{C}$. Unfortunately, there are no health-related studies regarding heat wave-related mortality from the MENA region to better quantify the risk. There are also no clear action plans to proactively deal with such heat waves within capital cities in the MENA.

Therefore, the consequences of climate change, even with a $2{ }^{\circ} \mathrm{C}$ scenario, are rather serious for the MENA region and will be felt well before the end of this century. Record temperatures are already being recorded in several countries.

\section{Desert Sand and Dust Storms}

The MENA region is a major source of desert dust storms travelling to Europe and Asia (Fig. 10.3). The higher temperatures affecting the region are leading to lower soil moisture and more arid conditions, which are exacerbated by lower precipitation and longer drought periods. Aridity is expected to increase by $50 \%$ throughout the entire coastal region if the business-as-usual model is followed (World Bank, 2014a). These conditions support more desert dust storms in the region. However, local conflicts played an important role in desertification and dust storms from the desert. The 1991 Gulf War and use of tanks and heavy equipment disrupted the desert ecology in Iraq, Kuwait, and Saudi Arabia (in areas which are now major sources of desert dust storms) with the topsoil becoming suspended as fine particles at higher levels in the air. There have been more frequent desert dust storms affecting the region in the last two decades. In Iraq, 122 dust storms were recorded in a single year in 2010 and are expected to more than double in incidence to around 300 dust storms a year in 2020 (UNEP, 2016). The size and type of dust particles also

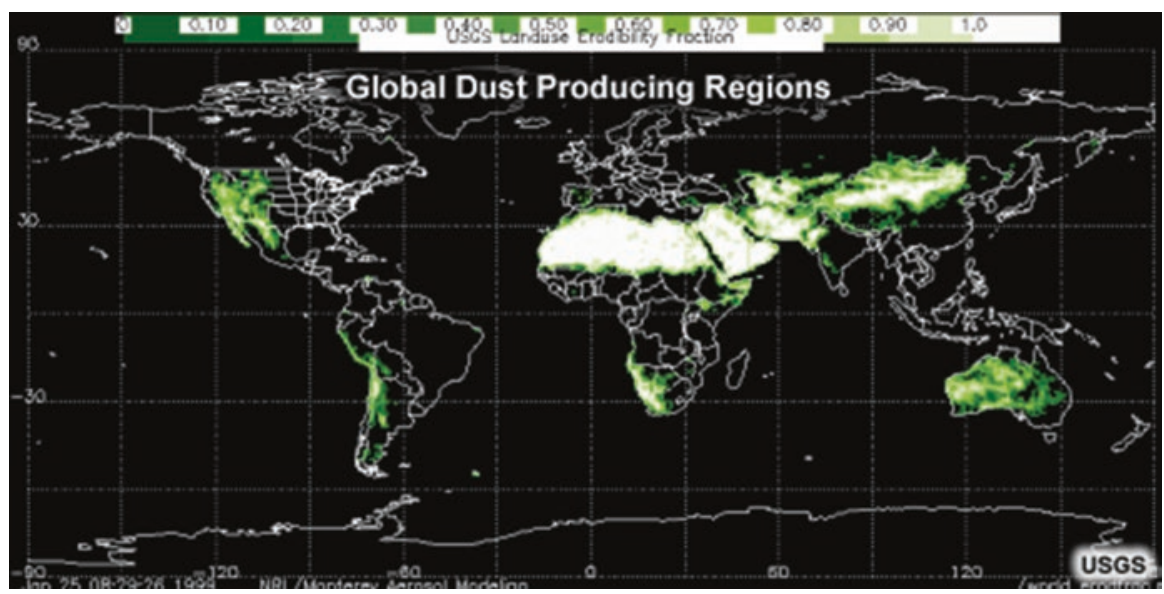

Fig. 10.3 The National Geospatial Program of the US Geological Survey map of origins of dust storms from the Middle East and North Africa region 

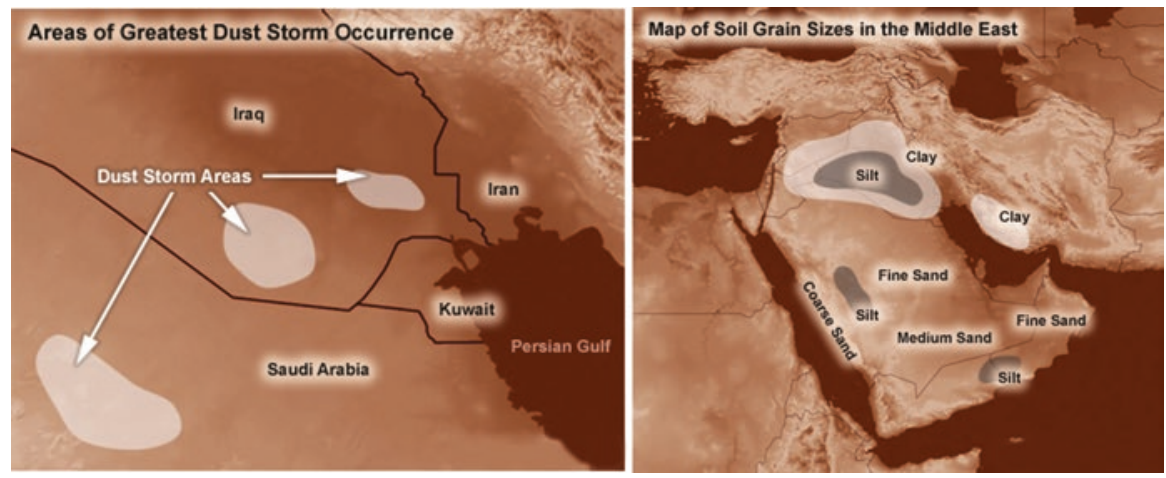

Fig. 10.4 Types of particles from the dust storms in the Middle East and the specific places with most frequent dust storms (From the Comet Program by NOAA National Weather Service)

have an impact on human health, where finer particles that are more common in the Arabian Peninsula (Fig. 10.4) reach deeper in the lung and cause more damage.

Frequent desert dust storms cause increased emergency visits for those with respiratory illnesses. We have demonstrated in a study from Japan that desert dust storms from the Taklamakan Desert in China led to a significant increase in asthma admission among children in Japan (Kanatani et al., 2010). The best-fit model adjusting for climate and other variables demonstrated an odds ratio (OR) of 1.71 (95\% CI 1.18-2.48; $p=0.005)$. OR was higher for boys at 2.32 (95\% CI 1.10-4.87; $p=0.005$ ) and for 6- to 12-year-olds at 3.33 (95\% CI 1.02-10.92). The impact of these desert dust storms will continue to inflict damage on these countries, but the level of health impact from these frequent dust storms is unknown for the MENA region.

There are other important health impacts of dust storms, including poor visibility, leading to more road traffic accidents. Dust storms have also been shown to carry bacteria and viruses for thousands of miles across the globe, with the bacteria types varying by region. Studies have documented microorganisms in dust from Tunisia (Hezbri et al., 2016), Lebanon (Itani \& Smith, 2016), Kuwait (Leski, Malanoski, Gregory, Lin, \& Stenger, 2011), and Iraq (Al-Dabbas, Ayad Abbas, \& Al-Khafaji, 2012). This has new implications and understandings for what might trigger certain medical conditions. Toxins and allergens are also carried on dust particles in dust storms (Abuduwailil, Zhaoyong, \& Fengqing, 2015; Kameda et al., 2016).

Climate change will specifically impact the health of populations in the MENA region through an increase in dust storms that are of higher frequency and wider geographical spread, affecting millions of people every year. There is a need for active adaptation approaches based on scientific evidence of who is at risk and what is the magnitude of that risk. 


\section{Water Scarcity}

All countries in the MENA region suffer from water shortage. The increase in drought and high temperatures with lower precipitation and increased demand will lead to scarcity in access to water. The MENA region will be the first region in the world to run out of fresh water. It is expected that water availability will decrease in most parts of the MENA region by $15 \%$ in a $2{ }^{\circ} \mathrm{C}$ scenario and up to $45 \%$ in parts of the region in a $4{ }^{\circ} \mathrm{C}$ scenario (World Bank, 2014a). Water access is mostly dependent on underground water or rain. The Gulf Countries have developed desalination projects to cover the supply of water, although this is at high financial and environmental costs.

Some of the countries with the poorest water supplies in the world are in the MENA region, namely Jordan and the Palestinian Territories under occupation of Israel. According to the Israeli Information Center for Human Rights in the Occupied Territories, Palestinians get as little as 20-50 L/day per capita compared to $287 \mathrm{~L} /$ day per capita for Israelis, while the WHO recommendation is to have a minimum of $100 \mathrm{~L}$ per capita per day (B'Tselem, 2016). The lack of water access is going to be exacerbated in that area because of overuse of underground water, lower precipitation, longer droughts and higher temperatures. Dwindling resources can trigger further conflict in an area already suffering from ongoing violence. It is estimated that the withdrawal-to-availability ratio for underground water in Jordan, Yemen, Libya, and most of the Gulf countries is more than 100\%, meaning that withdrawal is not being replenished and the water is going to be completely depleted (World Bank, 2014a). This is going to lead to lower local agricultural production and food insecurity.

Yemen is another country that is at the forefront of the water scarcity situation in the MENA region. It is the least able to adapt; has a growing population; lacks government control of water sources, which are dominated by local tribes; and has an ongoing conflict, which is preventing any policies or approaches to ration water or address the shortage (World Bank, 2014b). There is a 1.4 billion cubic meter shortfall in water supply per year, which is being met by water pumped up with modern tube wells or boreholes, depleting reserves of underground water. In rural areas, when wells run dry, social tensions escalate into local conflicts. Mass displacement from water scarcity causes migration and fuels the risk of wider conflicts (World Bank, 2014b). With Yemen being mostly an agricultural country, crops in Yemen are dying out because of water shortage leading to food insecurity, lower incomes, higher unemployment and more displacement. Although southern parts of Yemen are expected to have an increase in precipitation, this increase will be through extreme rain events that are likely to cause considerable damage to cropland and will not be enough to replenish underground water (World Bank, 2014a).

The above examples within the region give an indication of the volatility of the water situation in MENA and by no means cover all countries and challenges related to water scarcity. Water scarcity will bring with it a multitude of negative impacts in terms of agriculture and income, but also sanitation, violence and mass 
migration. Droughts will be most severe in the coastal areas of North Africa, leading to decreases in precipitation and a decline in rain-dependent agriculture and farming activities.

\section{Climate Change and Political Instability in Relation to Refugees}

Mass migration from flooding is expected to reach two billion at the global level by the end of this century. More people will move inland as a result of coastal flooding, becoming environmental refugees (Geisler \& Currens, 2017). In the MENA region, mass migration has largely been the result of violence and economic reasons.

There are attempts to link the refugee crises in Syria to global warming, citing the drought that preceded the Syrian war in 2009. This is championed by notable reporters such as Thomas Friedman and several other researchers (Kelley, Mohtadi, Cane, Seager, \& Kushnir, 2015); however, it might be an oversimplification of complex geopolitical interests by regional and worldwide powers to control the region. The evidence for climate change being responsible for the Arab Spring or the Syrian war is only correlational in nature, and there is no evidence it was responsible for this uprising. Such oversimplification ignores the history and political situation of Syria and these countries. This connection between environment and war is not new and originated from Malthus in the eighteenth century (Malthus, 1798). This concept has been applied elsewhere in the MENA region such as Darfur, but there are strong arguments against such an association (Verhoeven, 2011). Could the drought in Syria and rapid urbanization by its rural populations have exacerbated the uprising? It might have, but this cannot be said with certainty. There is anecdotal evidence that frustration over lack of water and drought by farmers made it easier to join a rebellion (Wendle, 2016). A more balanced explanation for the association between climate change and the Syrian war and other conflicts would be to label it as an eco-social or risk-multiplier (Butler, 2017), but the conflict would have happened regardless. The nature of this conflict goes back to decades of oppression; the rebellion against dictatorships and oppression started in one place and then spread elsewhere.

However, the risk is real regarding climate change leading to exacerbation or triggering mass movements and future conflicts that result from such crises. According to Brigadier General Stephen Cheney, a member of the US Department of State's Foreign Affairs Policy Board and CEO of the American Security Project, "Climate change could lead to a humanitarian crisis of epic proportions. We are already seeing migration of large numbers of people around the world because of food scarcity, water insecurity and extreme weather, and this is set to become the new normal. Climate change is acting as an accelerant of instability in parts of the world on Europe's footsteps, including the Middle East and Africa" (Carrington, 2017). 


\section{Health of Refugees}

Even though the initial trigger of the conflicts that led to the current refugee crises are not necessarily related to the environment, the environment does exacerbate the suffering of refugees. Challenges of extreme heat and cold, limited water access, unemployment, rising food prices because of agricultural land degradation and other factors relevant to climate change increase the suffering of refugees in their host transitional countries such as Jordan, Lebanon, Egypt and Turkey. It is worth noting that Jordan and Lebanon have the highest number of refugees per capita of their respective populations. Therefore, the burden from migration is to a large extent kept within the region. There was a massive refugee influx from transition countries to Europe, mainly through Turkey. This in turn encouraged other refugees coming from Afghanistan, Iraq, and sub-Saharan Africa to join the exodus and mass migration by foot and boats, as smugglers established routes of illegal migration to Europe. The Mediterranean Sea has become the graveyard for thousands who have drowned on their path to reach Italy or other European countries. Others who survived the journey suffer the trauma of losing loved ones in the war or during their dangerous path to Europe.

The health of refugees has been undermined by the lack of access to health care for basic medical needs and the limited resources available in transitional countries where they settle, such as Jordan, Lebanon, and Egypt. In Turkey, refugees generally have better access to health care. Refugees can also spread infectious diseases through their mass movement across countries and because of living in unsanitary conditions with no treatment, and limited or no access to health care (Vittecoq et al., 2014).

One of the most important and highly neglected health needs of refugees is recognition and treatment of mental illnesses among both adults and children. Historically, the region has had a stigma against mental illnesses and has a very limited number of psychiatrists, estimated to be in the order of one psychiatrist per 100,000-200,000 people. Trauma from the conflicts and displacement is a longterm cause of mental illnesses such as depression, anxiety, PTSD and suicide. While the focus of NGOs and countries that care for refugees is on food and shelter, mental illnesses are neglected and generations of children from Syria and other countries suffer silently from loss and displacement.

We have shown through our own research among Somali refugees in San Diego that mothers who have a history of severe trauma from before being resettled in the USA continue to suffer mental illnesses and are more likely to have children who suffer from depression or poor adjustment (East, Gahagan, \& Al-Delaimy, 2017). The trauma continues and might not heal like a physical illness. Therefore, poor mental health is going to be a major health impact of climate change in the MENA region among displaced populations, whether resulting from climate impacts on the environment and livelihood of populations in the region or from ongoing civil unrest and violence. 


\section{Solutions and Level of Preparedness}

There is, to some extent, an understanding of the consequences of climate change on the welfare of the countries in the MENA region by the governments of 11 countries that have submitted Intended Nationally Determined Contributions (INDC) as of September 2017 (Algeria, Bahrain, Egypt, Jordan, Saudi Arabia, Sudan, Qatar, UAE, Palestine, Tunisia, and Morocco). Submissions vary in details of actions and policies; the most comprehensive was Jordan's, which took a holistic approach and developed a climate action plan. These countries plan mitigation and adaptation strategies to a variable degree of detail. This is a positive indication, although there is an equal number of countries from the region that still have not submitted any INDC.

Some countries are generating specific data to support adaptation policies. One such example is a recent study from Morocco, which demonstrated a tripling in water deficit by 2050 due to increased demand, 30\% less precipitation, and decreased surface and underground water reserves (Seif-Ennasr et al., 2016). The authors proposed 38 adaptation measures to address the impact of climate change and demonstrated that the most cost-effective measure is water preservation and management. In Lebanon, there is a new direction towards conservation agriculture as an alternative to intensive conventional agriculture (Chalak et al., 2017). UAE is focusing on renewable energy and proposed the development of renewable energy and nuclear energy as partial replacement energy sources to reach $25 \%$ of its energy expenditure by 2020 (Paul, Al Tenaiji, \& Braimah, 2016). In Saudi Arabia, the focus is on water conservation by developing desalination plants, expanding water recycling processes and infrastructure, transitioning from domestic agriculture to outsourcing food products, and taking the reins on solar development to phase out fossil fuels. Saudi Arabia is doing just about everything it can to ensure domestic water resources will be available and accessible, and that it will be able to sustain these practices (DeNicola, Aburizaiza, Siddique, Khwaja, \& Carpenter, 2015).

Emergency heat wave adaptation plans should be implemented in each of the MENA countries by utilizing several such plans already in place elsewhere in the world. The same should be done for dust storms that are becoming more frequent; these storms require preparation and prevention for their health impacts on vulnerable populations through education and collection of data.

Solutions to decrease the impact of this major water shortage are possible but require much effort, better governance, and a shift in thinking towards new approaches and water conservation. Because the teaching of Islam indicates that not wasting water is part of the faith, this can be put into the context of climate change consequences for the predominately Muslim followers in MENA. Recycling water is another important approach that can help prepare populations to deal with water scarcity. Grey water $(\mathrm{GW})$, which is wastewater generated from domestic activities such as laundering, dishwashing, and bathing used to meet rising water demands, 
comprises $50-75 \%$ of residential wastewater and is distinct from black wastewater, which is collected from toilets (Eriksson, Auffarth, Henze, \& Ledin, 2002; Friedler, 2004). Adopting GW recycling practices on a large scale may lower freshwater demands and decrease groundwater extraction rates by up to $30-50 \%$; this can result in a decrease in the risk of aquifer salinization (Jeppesen, 1996). It has been found by our survey and review of the literature that the main limitation for use of GW is cost (Leas, Dare \& Al-Delaimy 2014). There is general cultural acceptability in MENA to use GW and no health-related impacts are reported, although more epidemiological studies are needed to document its safety for use. Further, scholars of Islam have already addressed the type of uses for GW that are allowed in Islam, including its use for irrigation (Leas, Dare \& Al-Delaimy 2014).

\section{Conclusions}

The MENA region is the global ground zero for climate change. It will be suffering catastrophic heat waves and, especially during several months in summer, will be beyond human capacity to be outdoors. It will be the first region to run out of fresh water, it has a population growth that will increase demand for resources, and it is suffering ongoing wars and civil unrest leading to displacement of mass populations. All of these have serious health consequences for the populations living in the region. Lower-income populations will suffer the most, as they are less likely to be protected by infrastructure or the means to adapt to this new environment brought by climate change. Water scarcity and frequent desert dust storms bring many adverse health consequences. There is also lack of awareness and education by the general population of these impending catastrophes in this century and local media coverage is very limited.

There is a need to support and encourage individual countries to aggressively address mitigation and adaptation measures for the sake of current and future generations living in this region. Civil unrest and wars will be a major barrier towards such efforts. However, as was done elsewhere in Latin America and Africa regarding vaccination programs to create peace, the climate change problem can become a unifying source in finding ways to work together to address the impact of climate change as the leading public health problem of the century. Religious bodies and entities in the region need to be informed and educated about the association between the Muslim faith and protection of the planet to prevent and reduce the health consequences of climate change. There is much at stake for the livelihood of the millions living in the MENA region, but also in the rest of the world, as witnessed by the mass displacements and refugee crises that have affected other regions. 


\section{References}

Abuduwailil, J., Zhaoyong, Z., \& Fengqing, J. (2015). Evaluation of the pollution and human health risks posed by heavy metals in the atmospheric dust in Ebinur Basin in Northwest China. Environmental Science and Pollution Research, 22, 14018-14031.

Al-Dabbas, M. A., Ayad Abbas, M., \& Al-Khafaji, R. M. (2012). Arabian Journal Geoscience, 5, 121.

B'Tselem. (2016, September 27). The Israeli Information Center for human rights in the occupied territories. Retrieved October 19, 2017, from http://www.btselem.org/water/ discrimination_in_water_supply

Butler, C. (2017). Limits to growth, planetary boundaries, and planetary health. Current Opinion in Environmental Sustainability, 25, 59-65.

Chalak, A., Irani, A., Chaaban, J., Bashour, I., Seyfert, K., Smoot, K., et al. (2017). Farmers' willingness to adopt conservation agriculture: New evidence from Lebanon. Environmental Management, 60, 693-704. https://doi.org/10.1007/s00267-017-0904-6

Damian Carrington. (2017, December 1). Climate change will stir unimaginable refugee crisis, says military. The Guardian.

DeNicola, E., Aburizaiza, O. S., Siddique, A., Khwaja, H., \& Carpenter, D. O. (2015). Climate change and water scarcity: The case of Saudi Arabia. Annals of Global Health, 81, 342-353.

East, P. L., Gahagan, S., \& Al-Delaimy, W. K. (2017). The impact of refugee mothers' trauma, posttraumatic stress, and depression on their children's adjustment. Journal of Immigration and Minority Health, 20(2), 271-282. https://doi.org/10.1007/s10903-017-0624-2

Eriksson, E., Auffarth, K., Henze, M., \& Ledin, A. (2002). Characteristics of grey wastewater. Urban Water, 4, 85-104.

Friedler, E. (2004). Quality of individual domestic greywater streams and its implication for onsite treatment and reuse possibilities. Environmental Technology, 25, 997-1008.

Geisler, C., \& Currens, B. (2017). Impediments to inland resettlement under conditions of accelerated sea level rise. Land Use Policy, 66, 322-330.

Guo, Y., Gasparrini, A., Armstrong, B. G., Tawatsupa, B., Tobias, A., Lavigine, E., et al. (2017). Heat wave and mortality: A multicountry, multicommunity study. Environmental Health Perspectives, 125, 087006.

Hezbri, K., Ghodhbane-Gtari, F., Montero-Calasanz, M. D., Nouioui, I., Rohde, M., Spröer, C., et al. (2016). Geodermatophilus pulveris sp. nov., agamma-radiation-resistant actinobacterium isolated from the Sahara desert. The International Journal of Systematic and Evolutionary Microbiology, 66, 3828-3834.

Itani, G. N., \& Smith, C. A. (2016). Dust rains deliver diverse assemblages of microorganisms to the Eastern Mediterranean. Scientific Reports, 6, 22657.

Jeppesen, B. (1996). Domestic greywater re-use: Australia's challenge for the future. Desalination, $106,311-315$.

Kameda, T., Azumi, E., Fukushima, A., Tang, N., Matsuki, A., Kamiya, Y., et al. (2016). Mineral dust aerosols promote the formation of toxic nitropolycyclic aromatic compounds. Scientific Reports, 6, 24427.

Kanatani KT, Ito I, Al-Delaimy WK, Adachi Y, Mathews WC, Ramsdell JW; Toyama Asian Desert Dust and Asthma Study Team. (2010) Desert dust exposure is associated with increased risk of asthma hospitalization in children. American Journal of Respiratory and Critical Care Medicine, 182, 1475-1481.

Kelley, C. P., Mohtadi, S., Cane, M. A., Seager, R., \& Kushnir, Y. (2015). Climate change in the Fertile Crescent and implications of the recent Syrian drought. Proceedings of the National Academy of Sciences of the United States of America, 112, 3241-3246.

Leas, E. C., Dare, A., \& Al-Delaimy, W. K. (2014). Is gray water the key to unlocking water for resource-poor areas of the Middle East, North Africa, and other arid regions of the world? Ambio, 43, 707-717.

Lelieveld, J., Proestos, Y., Hadjinicolaou, P., Tanarhte, M., Tyrlis, E., \& Zittis, G. (2016). Climatic Change, 137, 245-260. 
Leski, T. A., Malanoski, A. P., Gregory, M. J., Lin, B., \& Stenger, D. A. (2011). Application of a broad-range resequencing array for detection of pathogens in desert dust samples from Kuwait and Iraq. Applied and Environmental Microbiology, 77, 4285-4292.

Malthus, T. R. (1798). An essay on the principle of population. London. Retrieved October 7th 2019 from http://www.esp.org/books/malthus/population/malthus.pdf

Pal, J. S., \& Eltahir, E. A. B. (2016). Nature Climate Change, 6, 197-200, London. Retrieved October 7th 2019 from http://www.esp.org/books/malthus/population/malthus.pdf.

Paul, P., Al Tenaiji, A. K., \& Braimah, N. (2016). A review of the water and energy sectors and the use of a nexus approach in Abu Dhabi. International Journal of Environmental Research and Public Health, 13, 364. PMC.

Pew Research Center (2011, January 27). Religion and public life. Retrieved October 19, 2017 from http://www.pewforum.org/2011/01/27/future-of-the-global-muslim-population-regionalmiddle-east/

Robine, J. M., Cheung, S. L., Le Roy, S., et al. (2008). Death toll exceeded 70,000 in Europe during the summer of 2003. Comptes Rendus Biologies, 331, 171-178.

Seif-Ennasr, M., Zaaboul, R., Hirich, A., Caroletti, G. N., Bouchaou, L., El Morjani, Z. E., et al. (2016). Climate change and adaptive water management measures in Chtouka Aït Baha region (Morocco). Science of Total Environment, 573, 862-875.

Shaposhnikov, D., Revich, B., Bellander, T., Bedada, G. B., Bottai, M., Kharkova, T., et al. (2014). Mortality related to air pollution with the moscow heat wave and wildfire of 2010. Epidemiology, 25, 359-364. https://doi.org/10.1097/EDE.0000000000000090

UNEP (2016, June 14). Retrieved October 19, 2017, from https://www.unenvironment.org/ news-and-stories/story/more-action-needed-sand-and-dust-storms

Verhoeven, H. (2011). Climate change, conflict and development in Sudan: Global neo-Malthusian narratives and local power struggles. Development and Change, 42, 679-707.

Vittecoq, M., Thomas, F., Jourdain, E., Moutou, F., Renaud, F., et al. (2014). Risks of emerging infectious diseases: Evolving threats in a changing area, the Mediterranean basin. Transboundary and Emerging Diseases, 61, 17-27.

Wendle, J. (2016). Syria's climate refugees. Scientific American, 314, 50-55.

World Bank. (2014a). Turn down the heat: Confronting the new climate normal. Washington, DC: World Bank.

World Bank. (2014b). Future impact of climate change visible now in Yemen. Retrieved October 19, 2017, from http://www.worldbank.org/en/news/feature/2014/11/24/ future-impact-of-climate-change-visible-now-in-yemen

Ye, X., Wolff, R., Yu, W., Vaneckova, P., Pan, X., \& Tong, S. (2012). Ambient temperature and morbidity: A review of epidemiological evidence. Environmental Health Perspectives, 120, 19-28.

Open Access This chapter is licensed under the terms of the Creative Commons Attribution 4.0 International License (http://creativecommons.org/licenses/by/4.0/), which permits use, sharing, adaptation, distribution and reproduction in any medium or format, as long as you give appropriate credit to the original author(s) and the source, provide a link to the Creative Commons license and indicate if changes were made.

The images or other third party material in this chapter are included in the chapter's Creative Commons license, unless indicated otherwise in a credit line to the material. If material is not included in the chapter's Creative Commons license and your intended use is not permitted by statutory regulation or exceeds the permitted use, you will need to obtain permission directly from the copyright holder.

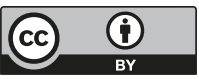

